\title{
Whistleblowing in Hungary
}

Attila Kun ${ }^{1}$

https://doi.org/10.18778/8220-639-5.07

\section{Introduction}

At present, whistleblowers' legal status is regulated in Hungary by a single legal act, namely Act CLXV of 2013 on complaints and public interest disclosures (hereinafter referred to as: Act on Pkbt., in brief: Pkbt., following the Hungarian abbreviation), which entered into force on $1^{\text {st }}$ January 2014.

At the time of the writing of this paper, ${ }^{2}$ no official information is available if the implementation (or the related preparatory works) of the Whistleblower Directive 3/4 Directive (EU) 2019/1937 of the European Parliament and of the Council of 23 October 2019 on the protection of persons who report breaches of Union law (hereinafter referred to as the Directive, or the Whistleblower Directive) has already started. The Member States are supposed to bring into force laws, regulations and administrative provisions necessary to comply with the Directive by 17 December 2021. As Abazi states, "the EU Whistleblower Directive is an important legal development but it is only in the early stages towards meaningful protection, rather than a 'game changer' for whistleblowers." ${ }^{3}$ It will be interesting to observe how post-socialist countries, including Hungary, will be able to meaningfully implement the standards of the Directive.

In this regard, the aim of this chapter is to take a general account of the past and current practices, experiences and challenges of whistleblowing legislation and whistleblower protection in Hungary. The emphasis will be put on the critical analysis of the currently effective regulatory environment of whistleblowing and whistleblower

1 Professor, Dr Attila Kun. Head of Department, Károli Gáspár University of the Reformed Church in Hungary (KRE), Faculty of Law, Department of Labour Law and Social Security; Professor, Hungarian National University of Public Service (NKE), Faculty of Public Governance and International Studies, Department of Human Resources. The study was conducted as part of the research of the MTA (Hungarian Academy of Sciences)-PTE Research Group of Comparative and European Employment Policy and Labour Law. This paper was supported by the János Bolyai Research Scholarship of the Hungarian Academy of Sciences. Supported by the ÚNKP20-5-KRE-2 New National Excellence Program of the Ministry for Innovation and Technology from the source of the National Research, Development and Innovation Fund.

2 The manuscript was closed in March 2021.

3 V. Abazi, The European Union Whistleblower Directive: A 'Game Changer' for Whistleblowing Protection?, Industrial Law Journal, Volume 49, Issue 4, December 2020, pp. 640-656. 
protection in Hungary, with specific regard to labour law aspects. Furthermore, the context, prospects and basic requirements of the future implementation of the Directive will also be highlighted. In this vein, Section 2 sketches the historical, societal and constitutional context. Section 3, as the central part of this study, examines in detail the currently effective legislative framework of whistleblowing in Hungary. Section 4 deals specifically with the labour law-related aspects of whistleblowing, while Section 5 takes a brief look into other related fields of law (including anti-discrimination, criminal law, and trade secrets). Section 6 considers recent and relevant critical opinions and motions for reform. Section 7 looks into the possible challenges and the main tentative tasks of the upcoming transposition of the Directive into Hungarian law. Finally, Section 8 draws some broad, general conclusions.

\section{Background: the historical, societal and constitutional context}

The first Hungarian whistleblower law was Act I of 1977 on public interest disclosures, recommendations, and complaints, which was in effect from 1977 until the country's accession to the EU in 2004. The main aim of this law was to uncover behaviours or facts which were illegal or contrary to "socialist morals" or the principles of socialist economy, or otherwise offended or endangered the interests of society. This act already provided for the protection of the discloser and also admitted anonymous reports. Between 2004 and 2009, only some basic, rather transitional rules concerning public interest disclosures were in force (NB: this is the Hungarian term for whistleblowing).

The next important milestone was Act CLXIII of 2009 on the protection of fair procedure and related amendments ("Fair Procedures Act"). In principle, it was a rather detailed and progressive piece of legislation covering also whistleblowing. It was modelled on certain experiences from the US. However, it provided for the establishment of a separate, dedicated Authority (in order to increase the efficiency of the fight against corruption), but this never came into being. As a result, this act remained lex imperfecta to a large extent.

As for the corporate practices of whistleblowing, according to a recent Hungarian survey, $94 \%$ of the responding companies had no "ethical infractions" in the last five years. Only $53.9 \%$ of the participating Hungarian corporations had a so-called code of ethics, while the international rate amounts to $81 \%$. Just $28.5 \%$ have a dedicated channel (ethics hotline), while globally this index is at $60 \%$. In sum, according to Ambrus, "the standards for combating corporate wrongdoing in Hungarian-owned companies do not correspond with international norms." ${ }^{3}$ Other experts are also

4 I. Ambrus, Considerations for Assessing Corporate Wrongdoings - a Hungarian Approach to Whistleblowing, Elte Law Journal, 2016/2, p. 9. 
generally sceptical about the Hungarian practice of whistleblowing. For instance, Dénes notes that in Hungary, there is limited practical possibility for a person who reports abuse to report anonymously in such a way that irregularities are actually detected and remedied as a result of the report. The lack of this real possibility significantly reduces the efficiency of the Hungarian abuse-reporting system. Dénes concludes that the "whistleblowing system does not work well in Hungary."

It is a historical heritage that while in the Anglo-Saxon countries the attitude towards whistleblowers is normally positive, in continental Europe and thus in Hungary there is often a kind of scepticism, a cultural aversion towards them. In addition, in post-socialist countries like Hungary, people often associate whistleblowing with the informant-systems of the totalitarian dictatorships of the $20^{\text {th }}$ century and treat the disclosers as informers and traitors. ${ }^{6}$

As regards the constitutional context, Article XXV of the Fundamental Law of Hungary (25 April 2011) stipulates that "Everyone shall have the right to submit either individually or jointly with others - a written request, complaint or proposal to any organ exercising executive powers."

\section{The currently effective legislative framework of whistleblowing in Hungary: the Pkbt. ${ }^{7}$}

\subsection{Material scope of protection}

The Pkbt. does not contain a list of breaches the disclosure of which justifies the whistleblower's status. The material scope is rather broad and undefined. The Pkbt. $[\$ 1(1)-(3)$ ] provides that public bodies and local government bodies shall assess complaints and public interest disclosures pursuant to this act. The law makes a difference between complaints and public interest disclosures. A complaint is a request for putting an end to a violation of individual rights or interests the assessment of which does not fall under the scope of any other proceedings, including in particular judicial or administrative proceedings. A complaint may also contain a proposal. A public interest disclosure (i.e. whistleblowing) draws attention to a circumstance the remedying or discontinuation of which is in the interest of the community or

5 E. Dénes, Whistleblowing: bejelentés vagy beárulás? (Whistleblowing: reporting or betrayal?), Munkajog (HVG-ORAC), 2020/4, pp. 37-44, p. 43.

6 E. Dénes, A. Kun, A whistleblowerek védelme - különös tekintettel a munkajogi aspektusokra (Protection of whistleblowers - in particular labour law aspects), Pécsi Munkajogi Közlemények, szeptember, IV. évf. II., 2011, pp. 113-145.

7 The official translation of the Pkbt. (which serves the basis for this Chapter, http://www.ajbh.hu/ documents/14315/130159/Act_CLXV_of_2013_.pdf/faa3e557-8e16-473f-1fa9-539e7cdb0f22, accessed 01/09/2021. 
the whole society. A public interest disclosure may also contain a proposal. Consequently, a public interest disclosure (i.e. whistleblowing) draws attention to any "circumstance the remedying or discontinuation of which is in the interest of the community or the whole society."

As regards whistleblowing systems maintained by employers (i.e.: internal whistleblowing, see below) - according to $\$ \$ 13-14$ Pkbt. - employers and their owners operating in the form of a company may define rules of conduct applicable to their employees in order to protect "a public interest or overriding private interest," "in order to provide their lawful and prudent operation." Again, the material scope is very broad and open-ended.

It must be noted that labour law infringements are not specifically covered. However, $\$ 16$ (4) Pkbt. stipulates that if the investigation reveals that the conduct reported by the whistleblower is not a crime but it constitutes a breach of the rules of conduct defined by the employer organization, the employer may impose employer sanctions on the employee concerned in accordance with the rules governing the employment relationship. Public interest disclosures may also play a role in relation to criminal law rules or, perhaps, another field of law (e.g. regulatory offences), as well as to civil law-related detriments such as negligence or violations of personal rights (e.g. those concerning reputation).

\subsection{Personal scope of protection}

According to $\$ 1$ (4) Pkbt., "anyone" may submit a complaint or a public interest disclosure to the body entitled to proceed in matters relating to the complaint and public interest disclosure. Thus, the logic of the Pkbt. is not employment-specific: "anyone" may submit a complaint or a public interest disclosure. Moreover, $\$ 11$ Pkbt. contains only a general clause on this matter ("protection of whistleblowers"): "With the exception of the actions referred to in Section 3(4) ["bad faith"], any action taken as a result of a public interest disclosure which may cause disadvantage to the whistleblower shall be unlawful even if it would otherwise be lawful."

As regards whistleblowing systems maintained by employers (i.e.: internal whistleblowing) - according to $\$ 14$ (1) Pkbt. - whistleblower reports may be submitted by the employees of the employers, by other persons having a contractual relationship with the employer organizations, or by persons who have an acceptable legitimate interest in submitting the whistleblower report or the remedying or discontinuation of the activity subject to the whistleblower report. $\$ 14$ (6) Pkbt. provides the following in this regard: "When making a whistleblower report, the whistleblower shall declare that the whistleblower report is made in good faith about circumstances that he or she is aware of or has a sufficient reason to believe that they are real. When making a whistleblower report, a whistleblower who is a legal person shall disclose its registered seat and the name of the legal representative of the person submitting the whistleblower report. Whistleblowers shall be reminded of the consequences of 
whistleblowing in bad faith, the rules governing the investigation of whistleblower reports, and the fact that the identity of the whistleblower - if he or she gives the data necessary to verify it - shall be treated confidentially in all stages of the investigation." Thus, according to the general opinion, a personal qualification is necessary, but this personal qualification is rather broad.

No specific rules exist concerning the extension of protection beyond the duration of the (employment etc.) contract. Furthermore, for instance, the relatives of whistleblowers are not protected.

\subsection{Internal reporting}

The Pkbt. allows organizations to establish distinct rules and procedures for handling disclosures and also to enter into agency contracts with lawyers for the purpose of receiving disclosures ("discloser protection lawyer"). Thus, the internal whistleblowing system is not obligatory. ${ }^{8}$ The operation of a whistleblowing system is optional for the companies; however, if they elect to set up such a system, it must comply with some standards of the law. The whistleblowing rules are published on the website of the company in Hungarian. The whistleblowing system must be based on the employer's publicly available code of ethics.

Alternatively, in line with $\$ \$ 17-18$ Pkbt., a legal person that is not considered to be a public body or a local government body ("the principal") may conclude an agency contract with a lawyer for the protection of whistleblowers to carry out activities relating to the reception and management of whistleblower reports concerning the activities of that legal person. ${ }^{9}$ For the purposes of the activities of the lawyer for the protection of whistleblowers, a whistleblower report covers all indications which draw the attention to a circumstance whose remedying or discontinuation is in the legal or lawful business interest of the principal or serve to put an end to an infringement that occurred in relation to the activities of the principal or to a threat to public security, public health or the environment. These "discloser protection

8 It must be noted that Government Decree 50/2013 (II. 25.) on the system of integrity management at public administration bodies and the procedural rules of receiving lobbyists prescribes that the head of the organization of public administration bodies shall be obliged to receive and investigate the reports on integrity and corruption risks with regard to the operation of the organization, in the framework of which they shall develop an internal regulation ( $\$ 4(1))$. However, the notion of whistleblowing implies a broader understanding, going beyond these "reports on integrity and corruption risks". Cf.: AJB-543/2021.

9 The lawyer engaged for the protection of whistleblowers is obliged to notify the regional bar association in writing about the conclusion of the agency contract within 15 days. The name, address, telephone number, e-mail address and website link of the lawyer for the protection of whistleblowers are published on the website of the regional bar association. For example, as for Budapest, currently only four lawyers (law firms) are registered as such (at the Budapest Bar Association), http://www.bpugyvedikamara.hu/az-on-ugyvedje/bejelentovedelmi-ugyved/, accessed 01/09/2021. 
lawyers" are on the borderline between internal and external reporting ${ }^{10}$ (being independent, but, after all, still "on the payroll" of the company).

$\$ \$ 13-16$ Pkbt. deal with "whistleblowing systems maintained by employers" (i.e.: internal whistleblowing) in further detail, providing for some basic procedural rules (including data protection).

According to $\$ 14$ Pkbt., in order to provide their lawful and prudent operation, employer organizations may set up whistleblowing systems for reporting violations of law as well as rules of conduct through which whistleblower reports may be submitted by the employees of the employers, by other persons having a contractual relationship with the employer organizations or by persons having acceptable legitimate interest in submitting the whistleblower report or the remedying or discontinuation of the activity subject to the whistleblower report. Employer organizations shall publish detailed information about the operation of their whistleblowing systems and their procedures relating to whistleblowing in Hungarian on their websites.

In the whistleblowing system, the employer organization may process the personal data, including also sensitive data and criminal personal data, of a) the whistleblower, and b) the person ba) whose activity or omission gave rise to the submission of the whistleblower report, or bb) who has relevant information concerning the substance of the whistleblower report (ba) and bb) hereinafter jointly referred to as "person concerned with the whistleblower report"] that is essential to the investigation of the whistleblower report only for the purposes of investigating the whistleblower report and remedying or discontinuing the reported conduct, and may transfer the data only to the lawyer for the protection of whistleblowers or to external organizations which participate in the investigation of the whistleblower report. Personal data processed within the whistleblowing system which does not fall under the above-mentioned rules has to be deleted immediately from the whistleblowing system.

When making a whistleblower report, the whistleblower has to declare that the whistleblower report is made in good faith about circumstances that he or she is aware of or with regard to which he or she has a sufficient reason to believe that they are real. When making a whistleblower report, a whistleblower who is a legal person has to disclose its registered seat and the name of the legal representative of the person submitting the whistleblower report. Whistleblowers have to be reminded of the consequences of whistleblowing in bad faith, the rules governing the investigation of whistleblower reports, and the fact that the identity of the whistleblower - if he or she gives the data necessary to verify it - will be treated confidentially in all stages of the investigation.

According to $₫ 15$ Pkbt., the data processed within the whistleblowing system is transferred to another state or international organization only if the addressee of the transfer undertakes a legal commitment with regard to the whistleblower report to

10 As Ambrus notes, this is a very "forward-thinking" solution of the Pkbt. I. Ambrus, Considerations for Assessing Corporate Wrongdoings - a Hungarian Approach to Whistleblowing, Elte Law Journal, 2016/2, p. 20. 
comply with the provisions of the Pkbt. Whistleblowing systems have to be designed so as to ensure that a non-anonymous whistleblower can be identified by no one but those who investigate the whistleblower report. Until the investigation is closed or formal prosecution is initiated as a result of the investigation, those who investigate the whistleblower report have to keep confidential all information about the substance of the whistleblower report and the persons concerned with it and, with the exception of informing the person concerned with the whistleblower report, may not share such information with any other organizational unit or employee of the employer organization. When opening an investigation, the person concerned with the whistleblower report has to be informed in detail about the whistleblower report as well as his or her right to protection of his or her personal data and the rules governing the processing of his or her data. In accordance with the requirement of fair proceedings, the person concerned with the whistleblower report has to be given an opportunity to state his or her views on the whistleblower report also through his or her legal representative and to provide supporting evidence. In exceptional and justified cases, the person concerned with the whistleblower report may be informed later if the immediate information would jeopardize the investigation of the whistleblower report.

According to $\$ 16 \mathrm{Pkbt}$., the employer organization investigates the whistleblower report in accordance with the procedures established by it and informs the whistleblower about the outcome of the investigation as well as the actions taken. A lawyer for the protection of whistleblowers may be entrusted to receive or investigate whistleblower reports under a contract, while a lawyer for the protection of whistleblowers or other external organizations may be entrusted to participate in investigating whistleblower reports.

The investigation of the whistleblower report may be omitted if:

a) the whistleblower submitted it without revealing his or her identity, ${ }^{11}$

b) it is a repeated whistleblower report made by the same whistleblower and its substance is the same as that of the previous one,

c) it was made by the whistleblower after six months of becoming aware of the activity or omission that he or she complains about;

d) the prejudice to public interest or overriding private interest is not proportionate to the limitation of the rights of the person concerned with the whistleblower report resulting from the investigation of the whistleblower report.

Whistleblower reports have to be investigated as soon as possible under the given circumstances but not later than 30 days after their receipt, which time limit is subject to derogation only in cases where it is highly justified, except where the whistleblower report was made anonymously or by an unidentifiable whistleblower,

11 Accordingly, anonymity is not fully supported. 
provided that the whistleblower is simultaneously informed. The investigation may not last longer than three months.

If the investigation of the conduct reported by the whistleblower warrants the initiation of criminal proceedings, arrangements have to be taken to ensure that the case is reported to the police (this is the so-called ex officio principle).

If the investigation reveals that the conduct reported by the whistleblower is not a crime but constitutes a breach of the rules of conduct defined by the employer organization, the employer may impose employer sanctions on the employee concerned in accordance with the rules governing the employment relationship.

If the investigation reveals that the whistleblower report is unfounded or that no further action is necessary, the data relating to the whistleblower report has to be deleted within 60 days of the conclusion of the investigation.

If any action is taken on the basis of the investigation, including actions due to legal proceedings or disciplinary action launched against the whistleblower, the data relating to the whistleblower report may be processed in the employer's whistleblowing system until the final conclusion of the proceedings launched on the basis of the whistleblower report.

No further specific legal guarantees are prescribed by law for internal investigations (in practice, there is a high risk that reports are investigated by people/bodies that are the subjects of the reports).

\subsection{External reporting}

\subsubsection{Complaints and public interest disclosures}

The Pkbt. [ $\$ 1$ (1)-(3)] stipulates that public bodies and local government bodies assess complaints and public interest disclosures. Accordingly, the law makes a difference between complaints and public interest disclosures, as it has been presented above. Pursuant to $\$ 1$ (4) Pkbt., if a public interest disclosure is made orally, the body entitled to proceed puts it in writing and gives its copy to the whistleblower. $₫ 1$ (5) Pkbt. provides that if a complaint or a public interest disclosure is submitted to a body other than the body entitled to proceed, it are referred to the body entitled to proceed within eight days of its receipt. The complainant or the whistleblower have to be simultaneously notified about the referral. If a public interest disclosure contains a proposal for new legislation or for an amendment of an existing piece of legislation, it is also forwarded to the relevant person or body having legislative power.

According to $₫ 2 \mathrm{Pkbt}$., as a main rule, complaints and public interest disclosures are assessed within thirty days of their receipt by the body entitled to proceed. If the investigation underlying the assessment is expected to last longer than thirty days, the complainant or the whistleblower have to be informed of the fact and of the expected date by which the complaint or the public interest disclosure will be assessed, as well as of the reasons for the prolonged investigation. If the substance 
of the complaint or the public interest disclosure makes it necessary, the body entitled to proceed hears the complainant or the whistleblower. Upon assessment of complaints or public interest disclosures, the body entitled to proceed immediately informs the complainant or the whistleblower about its actions or inaction, with the exception of classified data or data constituting trade, economic or other secrets pursuant to the law, specifying the reasons for its actions or inaction. Such information is not required to be given in writing if the complainant or the whistleblower has already been informed orally about the assessment of the complaint or the public interest disclosure and the complainant or the whistleblower has acknowledged that information.

As for data protection, $\$ 3$ (3) Pkbt. stipulates that - except in cases of bad faith - the personal data of the complainant or the whistleblower may not be handed over to any recipient other than the body competent to carry out proceedings on the basis of the respective complaint or public interest disclosure, provided that such body is entitled to process such data pursuant to the law, or the complainant or the whistleblower has given explicit consent to the forwarding of his or her data. Without such explicit consent, the personal data of the complainant or the whistleblower may not be made public.

When whistleblowers turn directly to the body they consider to be competent to take action in the given case, some uncertainties may arise. It is not clearly regulated whose responsibility it is to investigate whistleblower reports within the given public organisation. There is no general best practice in this regard and the Pkbt. does not clarify the issue, either. However, it must be mentioned that as a result of the integrity control systems introduced by a government decree in $2013,{ }^{12}$ the so-called integrity framework gives a central role to internal integrity advisors in public authorities. All public institutions need to designate such an advisor. ${ }^{13}$ Thus, it is quite likely that whistleblower reports would end up being received by these integrity advisors (who are subordinate report directly to the leader of the organisation).

\subsubsection{The protected electronic system for public interest disclosures: the role of the Commissioner for Fundamental Rights}

$\$ 4$ Pkbt. stipulates that public interest disclosures may be submitted also through a specific, designated protected electronic system for public interest disclosures. The Commissioner for Fundamental Rights $(C F R)^{14}$ - the Ombudsman - provides for the operation of the electronic system serving for filing and registering public interest disclosures. In fact, this is the (main) - and most convenient and most secure

12 50/2013. (II. 25.) Government Decree.

13 At the National University for Public Service (NUPS/NKE) there is a targeted university programme for becoming an integrity advisor.

14 Further details: Act CXI of 2011 on the Commissioner for Fundamental Rights (Act on CFR, Hungarian acronym: Ajbt). 
- external reporting channel in Hungary. Via the CFR, public interest disclosures can be made using the electronic system ${ }^{15}$ (on the interface established for this purpose on the homepage of the Office ${ }^{16}$ ) or in person at the customer service. According to $₫ 7 \mathrm{Pkbt}$., public interest disclosures or their excerpts (in cases of anonymity, see below) received through the electronic system have to be forwarded to the body entitled to proceed (i.e. the Office has no capacity or competences to investigate all cases). During the investigations, it is possible to contact the whistleblower via the electronic system.

In practice, the primary task of the Ombudsman is to forward the reports to competent authorities. These reports are not automatically transmitted to law enforcement authorities, and an administrative investigation is carried out instead first by the competent authorities themselves, usually (but not inevitably) via the integrity advisor of the institution concerned. Integrity advisors report directly to their head of institution. Either upon request or ex officio, the Ombudsman may, however, examine whether those authorities have followed up appropriately on the reports. The public interest disclosures are investigated by the institutions concerned, and their answer containing the result of the investigation is uploaded to an electronic registry. ${ }^{17}$

More precisely, according to the Act on CFR (38/A.\$), the CFR inquires into the practices of authorities in handling public interest disclosures made in accordance with the Pkbt. and, upon request, into the proper handling of certain public interest disclosures. According to the Act on CFR (38/C.\$), a whistleblower may submit a petition requesting the CFR to remedy a perceived impropriety if a) a public interest disclosure is qualified as unfounded by the competent authority, b) the whistleblower does not agree with the conclusions of the investigation, and c) according to the whistleblower, the competent authority has failed to conduct a comprehensive inquiry into a public interest disclosure. The outcome of such an investigation can be a report that is not legally binding. However, the acting body must report back. The acting body may accept or reject the recommendations of the Commissioner.

In relation to the specific protected electronic system for public interest disclosures (operated by the CFR), the following rules of data protection apply. $\$ 4$ (2) Pkbt. provides that the personal data processed in the electronic system may be processed only for the purposes of investigating the relevant public interest disclosure and keeping contact with the whistleblower. The identification data stored in the electronic system includes the name and address of the whistleblower [ $\$ 4$ (4) Pkbt.]. $\$ 5$ Pkbt. contains further rules in this regard: the electronic system assigns a unique identification number to each public interest disclosure received if the data referred above is made available by the whistleblower. The Commissioner for

15 http://www.ajbh.hu/kozerdeku-bejelentes-benyujtasa, accessed 01/09/2021.

16 http://www.ajbh.hu/kezdolap, accessed 01/09/2021.

17 European Commission (2020): 2020 Rule of Law Report Country Chapter on the rule of law situation in Hungary, Brussels, 30.9.2020 SWD(2020) 316 final, 12. 
Fundamental Rights discloses on the Internet a brief summary of the substance, excluding personal and specific institutional data, and the status of each public interest disclosure submitted through the electronic system, using their unique identification numbers. ${ }^{18}$ When a case has been closed, the name of the body involved in the public interest disclosure and, if different, the name of the body entitled to proceed are also made public. The electronic system has to be designed so as to enable contact with the whistleblower on the basis of the unique identification number and the password entered by the whistleblower. The electronic system has to be designed so as to enable the whistleblower to print and record in electronic form the entire content of the public interest disclosure.

In 2020, 316 submissions were received via this electronic system to the Office of the CFR, which corresponded to the average of the previous five years. Out of the 316 submissions, 232 (i.e. 84\%) were genuine public interest disclosures. $80 \%$ of these reports were anonymous. More or less half of the public interest disclosures turned out to be well-founded. Most of the cases involved the following topics: illegal dumping, water pollution; transport, conditions of roads; education and health care-related grievances during the Covid-related emergency situation; consumer protection, building authority procedures; activities of the police in relation to minor offences, etc. ${ }^{19}$

In general, it seems that the system for public interest disclosures via the CFR has been well institutionalised. When it comes to anonymity, it has become the most important external channel for reporting and is used quite extensively. Consequently, the preservation (and the possible improvement) of this mechanism seems to be reasonable.

\subsection{Anonymous disclosures}

As a main rule $[\$ 2 / \mathrm{A} .(3)-(4) \mathrm{Pkbt}$.], the competent authority has to refrain from examining a complaint or a public interest disclosure made by an unidentifiable person (i.e. anonymity is not supported). However, the competent authority may not follow this rule and may still examine the complaint or public interest disclosure in those cases where the complaint or public interest disclosure is based on a serious violation of rights or interests. It must be noted that there are no specific judicial or extrajudicial procedures of appeal institutionalised against the decisions concerning anonymity. It is the competence of the Commissioner for Fundamental

18 The Database is available here (in Hungarian), http://www.ajbh.hu/kozerdeku-bejelentes-publikus-kivonat, accessed 01/09/2021.

19 Alapvető Jogok Biztosának Hivatala, Beszámoló az Alapvető Jogok Biztosának és Helyetteseinek Tevékenységéröl 2020 (Office of the Commissioner for Fundamental Rights: Report on the Activities of the Commissioner for Fundamental Rights and his Deputies 2020), B/15278, pp. 106-108. 
Rights to inquire into the practices of competent authorities regarding anonymity. As a result of inquiring into their practice, the Commissioner may report to the National Authority for Data Protection and Freedom of Information.

In contrast to the main rule described above, according to $₫ 6$ Pkbt., whistleblowers making a public interest disclosure to the Commissioner for Fundamental Rights through the specific protected electronic system may request that their personal data are made available only to the Commissioner for Fundamental Rights and the Office of the Commissioner for Fundamental Rights. In this case, the Commissioner for Fundamental Rights prepares an excerpt about the public interest disclosure in order to ensure that it does not contain any data that may enable the identification of the whistleblower. In these cases, the investigation of the public interest disclosure (by the competent body) is not omitted on the grounds that the whistleblower cannot be identified by the body entitled to proceed.

As it was mentioned above, as regards internal reporting, the investigation of the whistleblower report may be omitted if the whistleblower submitted it without revealing his or her identity [ $\$ 16 .(1 b)$ a) Pkbt.].

\subsection{Public whistleblowing}

No specific, targeted protection is guaranteed under Hungarian law (in the Pkbt. more specifically) for whistleblowers turning directly to the public (including the media).

On the general level, as regards freedom of expression of employees and its limits, $\$ 8$ (3) of the Labour Code (Act I of 2012, hereinafter referred to as the Labour Code) provides that "employees may not exercise the right to express their opinion in such a way that it may lead to causing serious harm or damage to the employer's reputation or legitimate economic and organizational interests."

\subsection{Protection against reprisal according to the Pkbt.}

Hungarian law (i.e. the Pkbt.) does not stipulate a prescribed list of possible unlawful retaliatory measures against the whistleblower. $\$ 11$ Pkbt. contains only a general clause on this matter ("protection of whistleblowers"): "With the exception of the actions referred to in Section 3(4) ["bad faith"], any action taken as a result of a public interest disclosure which may cause disadvantage to the whistleblower shall be unlawful even if it would otherwise be lawful." This resembles a mere declaration without specific rules. $\$ 3$ (2) Pkbt. likewise stipulates that - except for the case of "bad faith" - complainants and whistleblowers shall not suffer any disadvantage for making a complaint or a public interest disclosure.

Furthermore, $\$ 12 \mathrm{Pkbt}$. states that with the exception of the case referred to in Section 3(4) ["bad faith"], a whistleblower qualifies to be at risk if the disadvantages threatening him or her as a result of the public interest disclosure that he or she 
made are likely to seriously endanger his or her life circumstance. A whistleblower who is a natural person is entitled to aids provided to ensure his or her protection, as defined in the relevant law, if he or she is likely to be at risk. The state has to provide the aids defined in Act LXXX of 2003 on legal aid to whistleblowers under the conditions defined in the same act. However, it is not clear from these rules who (which body) - and on what basis - is competent to qualify a whistleblower as being "at risk," and in practice, this rule seems to be ineffective. In his Report No. AJB-1873/2017 (published on his website), the Commissioner stated that the relevant legal regulations are not clear and adequately detailed concerning the support measures either in the Act on Pkbt. or in the Act on Legal Aid. Furthermore, it is not clearly defined which authority shall establish that the whistleblower is at risk.

Concerning financial incentives, $₫ 19$ Pkbt. provides that the minister responsible for justice is authorized to determine by way of a decree the aids available to whistleblowers qualified as being at risk and the rules governing the disbursement of such aids. However, no such regulation is in force; it has never been adopted.

\section{Whistleblowing and labour law}

\subsection{Aspects of individual labour law}

Employees-whistleblowers are entitled to make a claim in the case of unlawful, wrongful termination of the employment relationship in line with the general rules of the Labour Code, i.e. there are no whistleblowing-specific rules in this regard. In other words: if the whistleblower's employment is terminated as a result of his or her whistleblowing activity, the dismissal can be considered unlawful and the whistleblower may initiate a labour-rights dispute.

The new Labour Code (Act I of 2012) introduced a number of fundamental changes affecting employment contracts law and individual labour law. However, a conceptual change with the most far-reaching consequences certainly has affected the rules related to the legal protection against unlawful dismissal. In short, the new Labour Code reduces the legal protection against unlawful dismissal. By contrast, the "old Labour Code" stipulated that when a court found that an employer had unlawfully terminated an employee's employment, the employee could request to continue being employed in his or her original position ("reinstatement"). According to these old rules, the court could in such circumstances and at the employer's request release the employer from having to reinstate the employee in his or her original position, if the continued employment of the employee could not be expected of the employer. Should the employee not request to be reinstated in his or her original position or should the court release the employer from this obligation, the court was empowered, after weighing all applicable circumstances, to order 
that the employer pay not less than two and not more than twelve months' average earnings to the employee (as a kind of punitive sanction). In such cases, the employment relationship was deemed to have terminated on the day the court handed down its ruling on the unlawfulness of the action. In the case of unlawful dismissal, the employee was to be - virtually automatically - reimbursed for lost wages (and other emoluments) and compensated for any damages arising from such loss. The portion of wages (and other emoluments) or damages recovered otherwise was to be neither reimbursed nor compensated.

Under the new provisions ( $\$ 82-83$ of the Labour Code), there are no more general obligations for re-instatement (i.e. re-instatement becomes a very exceptional possibility ${ }^{20}$. In the old system, compensation of lost wages was quasi-automatic and without limits and it was due for the whole duration of the lawsuit (which, without doubt, was not fully fair for employers). Furthermore, legally speaking, the employee was not obliged to mitigate the costs. In the new system, the employer is obliged to provide financial compensation for all losses caused through the unlawful dismissal with a view to the rules on liability for damages (as a consequence, justification becomes more difficult and complex as the employee needs to show that he or she has suffered a real damage in relation to the unjust dismissal). Moreover, there is a statutory limit on the most typical share of damages: the damages - as lost earnings - thus paid may not exceed the total amount of the employee's twelve-month absence pay. Furthermore, the "punitive sanction" (2-12 months' salary in the former scheme) is completely ruled out under the new system. Accordingly, the gravity of the breach of law is irrelevant in the current system and the legal consequences of unjust dismissal (if any) are determined solely by the proven actual harm suffered by the employee (in line with the logic of liability for damages). In lieu of being able or eager to show the actual damage, the employee may demand a lump-sum payment equal to the sum of absentee pay due for the notice period when his or her employment is terminated by the employer (in practice, this lump sum payment is usually relatively low and offers not enough motivation to start a lawsuit).

Furthermore, the Curia (the highest judicial authority in Hungary) is of the opinion that no payment ("sérelemdíj" in Hungarian) for the violation of personality rights (which replaced non-pecuniary damages) can be claimed solely on the ground of unlawful dismissal, in the absence of any additional elements constituting a violation of personality rights.

All in all, sanctions for unlawful termination of the employment relationship are drastically limited in the new Code. The overall purpose of the reform was to reduce the large number of litigious proceedings (which is, in our opinion, a very debatable regulatory idea). As a result, the legal consequences of unlawful terminations are

20 Reinstatement is not specifically granted in relation to retaliatory dismissal in connection with whistleblowing. However, if the retaliatory measure (i.e. the termination) against the whistleblower also qualifies as discrimination, reinstatement might apply. 
revised and moderated in order to avoid solutions which forced the employers to pay excessive, unproportionately high amounts. As Gyulavári and Kártyás describe it, "the new rules shifted the emphasis from punishing the employer and full reparation of damages to recovering only a very limited part of the damages incurred by the employee in [the] case of wrongful dismissal." They continue by stating that it is questionable whether the employee receives appropriate reparation and whether the employer is efficiently restrained from introducing similar unlawful measures. ${ }^{21}$ All in all, a large number of unlawful terminations can remain without any sanction, as employees will not be motivated enough to file a case. ${ }^{22}$

One cannot find too many decisions dealing specifically with whistleblowing in the Hungarian judicial practice. ${ }^{23}$ In a classic, almost four decades' old case, the court found that even a seemingly lawful dismissal was unlawful if the purpose of the dismissal was to remove the reporting employee, because the requirement that the grounds for termination must be reasonable was infringed, so that termination could not be lawful. ${ }^{24}$ However, the existing case law is clear that the mere fact of a public interest disclosure (whistleblowing) does not provide full or absolute automatic protection for the employee against termination of employment. ${ }^{25}$ In one more recent case, the court found that if the reason for dismissal or immediate termination met the general requirements of the law, the employer's action would not be unlawful even if the employee had otherwise made a public interest disclosure. On this basis, it is for the court to determine whether the employer's reasons are in fact aimed at seeking revenge on the employee or whether they are real, clear, reasonable and independent of the report. Thus, dismissal by the employer is not unlawful if the employee, in disregard of a substantial obligation, continues to act in a manner which is unfair to his or her employer and thereby breaches his or her obligation to cooperate. ${ }^{26}$ Furthermore, the employer may also impose sanctions - under some conditions - on the employee, if the reason is the disclosure itself. Judicial practice admits this if it becomes clear that the whistleblower acted in bad faith on the basis of false information. ${ }^{27}$

21 T. Gyulavári, G. Kártyás, The Hungarian Flexicurity Pathway? New Labour Code after Twenty Years in the Market Economy, Pázmány Press, Budapest 2015, p. 40.

22 For further details see: A. Kun, International Research Project DIADSE (Dialogue for Advancing Social Europe), Country Report - Hungary, 2017; (Project financed by the EU, European Commission DG Employment, Social Affairs and Inclusion, Social Dialogue, Industrial Relations; Agreement number. VS/2014/0530), Project Management: Universiteit van Amsterdam, Hugo S. Instituut), http://hsi.uva.nl/en/diadse/reports/reports.html, accessed 1/09/2021.

23 For an overview see: E. Dénes, Whistleblowing: bejelentés vagy beárulás? (Whistleblowing: reporting or betrayal?), Munkajog (HVG-ORAC), 2020/4, p. 42.

24 BH 1979.39.

25 E. Dénes, Whistleblowing: bejelentés vagy beárulás? (Whistleblowing: reporting or betrayal?), Munkajog (HVG-ORAC), 2020/4, p. 42.

$26 \mathrm{BH} 2009.255$.

27 BH 2003.344. 
It is noteworthy that in practice, some form of labour law-like protection can also derive from data protection law (in line with the GDPR ${ }^{28}$ ). For instance, the National Authority for Data Protection and Freedom of Information (hereinafter referred to as the NAIH, according to the Hungarian abbreviation) in a seminal case imposed a fine of EUR 3,100 on a local government after an employee of an organization that it supervised reported a public interest complaint directly to it against his employer. After the organization learned of the complaint, it requested details in order to investigate, and the local government accidentally revealed the complainant's name. The NAIH considered it an aggravating factor that as a result of the data breach, the organization fired the person who made the report. ${ }^{29}$ Furthermore, the NAIH published a guidance on the basic requirements for workplace-related data management in 2016. This document contains some targeted information on whistleblowing systems (in line with the Pkbt.). ${ }^{30}$

It should be noted that in the public sector, the Code of Professional Ethics of the Faculty of Hungarian Government Officials (in Hungarian: A Magyar Kormánytisztviselői Kar - MKK - Hivatásetikai Kódexe) contains some specific (ethical) guidelines on reporting abuses (III./1.). ${ }^{31}$

\subsection{Aspects of collective labour law}

The role of workers' representatives (trade unions or works councils) in relation to whistleblowing is not clarified in Hungarian law. However, the general rules of the Labour Code ( $\$ 264$ ) provide that employers have to consult the works council prior to passing a decision in respect of any plans for actions and adopting regulations affecting a large number of employees, including, among others, a measure in relation to the protection of personal data of the employees. This rule might in principle apply to whistleblowing schemes (and related internal regulations), as well.

Concerning employees' representatives, the Labour Code sets very strict confidentiality obligations. $\$ 234(2)-(3)$ of the Labour Code provide that the representatives acting in the name and on behalf of works councils or trade unions are not authorised to disclose any facts, information, know-how or data which, in the legitimate economic interest of the employer or in the protection of its functioning, have expressly been provided to them in confidence or need to be treated as business

28 Regulation (EU) 2016/679 of the European Parliament and of the Council of 27 April 2016 on the protection of natural persons with regard to the processing of personal data and on the free movement of such data, and repealing Directive 95/46/EC (General Data Protection Regulation), OJ L 119, 4.5.2016, p. 1-88.

$29 \mathrm{NAlH} / 2019 / 596 / 3$, https://www.naih.hu/files/NAlH-2019-596-hatarozat.pdf, accessed 01/09/2021.

30 https://www.naih.hu/files/2016_11_15_Tajekoztato_munkahelyi_adatkezelesek.pdf, accessed 01/09/2021.

31 http://mkk.org.hu/node/485, accessed 01/09/2021. 
secrets, in any way or form, and are not authorised to use them in any other way in connection with any activity in which this person is involved for reasons other than the objectives specified in the LC. Furthermore, any person acting in the name or on behalf of the works council or trade union is authorised to disclose any information or data acquired in the course of his or her activities solely in a manner which does not jeopardise the employer's legitimate economic interest and without violating rights relating to personality.

\section{Whistleblowing and some other relevant fields of law}

\subsection{Whistleblowing and anti-discrimination}

The legal framework for anti-discrimination is set out in Act CXXV of 2003 on equal treatment and the promotion of equal opportunities (hereinafter referred to as the Ebktv. following the Hungarian abbreviation). One of the most frequently arising issues is the question of how to interpret the concept of "other situation, characteristic or feature" in $\$ 8(\mathrm{t})$ of the Ebktv. The protected characteristics are the characteristics and features enumerated in the Ebktv. from point a) to $t$ ), including nineteen plus one characteristics. The law considers discrimination on the basis of these characteristics unlawful because it runs afoul of the principle of equal treatment. It is apparent that the Ebktv. tends to grant protection to characteristics that are typically innate and permanent and which either cannot be changed by the individual or are difficult to change for him or her. In line with international practice, the characteristics protected by the Ebktv. tend to be those that pertain to an essential feature of human personality; that may serve as the basis of group formation; that may be used as a basis of prejudice; and which are associated with some type of underprivileged situation. The enumeration of protected characteristics in the law is open-ended; the last ("plus") one mentioned is "other situation, characteristic or feature" in Section 8 (t). This does not imply, however, that the law affords protection based on any characteristic or situation that might conceivably apply to an individual, for that would render the regulation meaningless. The range of characteristics and situations protected under this concept must be similar to the characteristics explicitly listed in the law. The concept of other situation must be construed narrowly (see also: the Advisory Board Position Paper No. 288/2/2010 (IV.9) on the definition of other situation ${ }^{32}$ ). Generally, the concept of other situation does

32 See also: Curia - 4/2017 (XI.28.) KMK vélemény az egyenlő bánásmód követelményének megsértésével kapcsolatos munkaügyi perek egyes kérdéseiről (KMK opinion on the equal treatment requirement on certain aspects of labour lawsuits relating to breaches of the right to equal treatment). 
not apply if the disadvantage suffered is associated with the petitioner's individual circumstances - if it is based on the employer's personal antipathy, for example, or on a difference in opinion or personal conflict between a manager and a subordinated employee. Whistleblowing is not specifically covered and there is a low probability that the court (or the relevant authority) would interpret whistleblowing as "other situation, characteristic or feature."

According to $\$ 19$ Ebktv., a reversed (shared) burden of proof applies in procedures initiated in connection with the alleged violation of the principle of equal treatment, which includes procedures conducted by relevant authority. However, this unique rule on the reversed (shared) burden of proof is not relevant in cases related to whistleblowing (see above).

\subsection{Whistleblowing and some aspects of criminal law}

As for external whistleblowing, according to $₫ 3$ (4) Pkbt., in cases where it has become clear that the complainant or the whistleblower communicated untrue information of crucial importance in bad faith and it gives rise to an indication that a crime or an infraction was committed, the personal data of the complainant or the whistleblower has to be handed over to the body or person entitled to carry out proceedings (similarly, if there is good reason to consider it likely that the complainant or the whistleblower caused unlawful damage or other harm to the rights of others, his or her personal data is handed over to the body or person entitled to initiate or carry out proceedings upon the body or person's request).

As for internal whistleblowing, $\$ 16$ (3) Pkbt. stipulates that if the investigation of the conduct reported by the whistleblower warrants the initiation of criminal proceedings, arrangements have to be taken to ensure that the case is reported to the police (this can be labelled the so-called ex officio principle)..$^{33}$

It must be noted that $\$ 257$ of Act IV of 1978 (the previous criminal code) criminalized the initiation of any disadvantageous measures against a person making a public interest disclosure up until 31 January 2013 (the offence of persecution of a public interest discloser). Such an act is now classified as only a regulatory offence (as per $\$ 206 /$ A of Act II of 2012 on regulatory offences, regulatory offences procedure and the Regulatory Offence Registry System): any person who causes disadvantage to the whistleblower commits an offence. The police has competence in the procedure.

33 According to Ambrus, the "ex officio" principle (i.e. the duty to make a criminal complaint) is highly debatable and problematic in practice (i.e. there is not always a pressing social interest to warrant the use of the state's punitive powers). I. Ambrus, Considerations for Assessing Corporate Wrongdoings - a Hungarian Approach to Whistleblowing, Elte Law Journal, 2016/2, p. 20. 


\subsection{Whistleblowing and protection of trade secrets}

The Hungarian Parliament adopted a special act on the protection of trade secrets in 2018 (Act LIV of 2018 on the protection of business secrets). The Act starts with definitions related to the protection of trade secrets followed by clearly set procedural rules on exercising rights pertaining to the protection of trade secrets. The fundamental novelty of the Act is that it ensures the protection of trade secrets as a special way of protection similar to the concept and regulatory framework of intellectual property rights, whereas the previous concept under the Civil Code regarded trade secret as a part of privacy. According to $₫ 1(1)$ of the new law, trade secret "shall include any confidential fact, information and other data, or a compilation thereof, connected to economic activities, which are not publicly known in whole or in the complexity of their elements, or which are not easily accessible to other operators pursuing the same economic activities, where the proprietor of the secret has taken reasonable efforts that may be expected in the given circumstances to keep such information confidential." It is important to underline that $\$ 5(3)$ (b) of this act provides that the acquisition of the business secret shall not be construed an infringement where the acquisition of a business secret and its disclosure to the proper authority was done for the purpose of protecting the general public interest in preventing or combating any illegal activity or any misconduct or wrongdoing violating the general requirements of honest commercial practices, to the extent justified by its purpose.

In this regard, $\$ 8(4)$ of the Labour Code stipulates that employees have to maintain confidentiality in relation to business secrets obtained in the course of their work. Moreover, employees may not disclose to unauthorised persons any data learned in connection with their activities that, if revealed, would result in detrimental consequences for the employer or other persons. The requirement of confidentiality does not apply to any information that under specific other legislation should be treated as information of public interest or public information and as such is rendered subject to disclosure requirement. It is noteworthy that the Pkbt. does not clearly set aside this strict labour-law based duty of confidentiality. In sum, the connection between the Labour Code's strict confidentiality rule (as stated above) and whistleblowing is not specifically clarified in legislation (or in judicial practice).

\section{Critical opinions and motions for reform}

Some prominent non-governmental organisations dealing with whistleblower protection in Hungary are the following: K-Monitor, ${ }^{34}$ Hungarian Civil Liberties

34 https://k-monitor.hu/fooldal, accessed 01/09/2021. 
Union (HCLU), ${ }^{35}$ Transparency International Hungary ${ }^{36}$ etc. These NGOs often express criticism and put forward proposals in relation to whistleblower protection (however, it must be noted that the whole topic of anti-corruption is inherently over-politicised, and sometimes it is difficult to perceive these debates and opinions objectively, without the political context). For instance, Transparency International Hungary addressed an open letter to the President of the Republic in order to try to stop the promulgation of Pkbt. in 2013. The open letter contained a call for more effective fight against corruption and more concrete protection for whistleblowers. ${ }^{37}$ Furthermore, the Hungarian Civil Liberties Union and K-Monitor Watchdog for Public Funds prepared a submission for consideration by the UN Special Rapporteur on the Protection and Promotion of the Right to Freedom of Opinion and Expression on the Hungarian legal framework and practices governing whistleblower protection in August 2015. ${ }^{38}$ They fundamentally criticise the Pkbt. for providing poor protections to employees and citizens who report crime and corruption. The submission enumerates the main shortcomings of the law from the perspective of these NGOs. Among others, the following generally relevant concerns are mentioned about the Pkbt. ${ }^{39}$ lack of specific remedies for victimised whistleblowers to be reinstated or compensated; the law bans retaliation but lacks the specific means to protect whistleblowers from reprisals, criminal prosecution and civil actions; the law does not provide a full range of disclosure channels; it does not require results of investigations to be released to the public; it does not require workplace retaliation and harassment to be investigated and remedied; relatives of whistleblowers are not protected; anonymous reporting is not supported etc. They also note that the Ombudsman often forwards reports and complaints to the very same ministry or agency that is responsible for the misconduct. The law only provides a formal way of appeal, since the Ombudsman's Office has neither the empowerment nor the capacities to conduct substantive investigations. The NGOs also point out that although detrimental measures against the whistleblower can only be justified if their misconduct is proven, in the case of a suspicion of wrongdoing, proceedings aiming to reveal a possible crime are not considered detrimental measures. This means that

35 https://hclu.hu/en, accessed 01/09/2021.

36 https://transparency.hu/en/, accessed 01/09/2021.

37 https://transparency.hu/kozszektor/kozerdeku-bejelentok-vedelme/allasfoglalasok-kutatasok/a-ti-nyilt-levele-dr-ader-janos-koztarsasagi-elnok-urhoz-a-kozerdeku-bejelentok-vedelme-erdekeben/, accessed 01/09/2021.

38 K-Monitor, Hungarian Civil Liberties Union, Submission to the Special Rapporteur on the promotion and protection of the right to freedom of opinion and expression on the Hungarian legal framework and practices governing whistleblower protection, 2015, https://www.ohchr.org/Documents/Issues/Opinion/Protection/HungarianCivilLibertiesUnion.docx, accessed 01/09/2021.

39 See also: "A Change of Direction" project, August, 2015, K-Monitor, Hungarian Civil Liberties Union, https://www.changeofdirection.eu/campaign-central/shortcomings-in-hungarys-whistleblower-law, accessed 01/09/2021. 
the protection guaranteed by the law does not prevail in practice. In conclusion, it is stated in the above-mentioned submission that "the current law does not provide sufficient protection to whistleblowers, and has to be reshaped fundamentally." ${ }^{40}$

A Report (2017) of the Commissioner for Fundamental Rights ${ }^{41}$ also included some critical remarks about the legislation concerning whistleblowing. For instance, it was mentioned that relevant legal regulations are not clear and adequately detailed concerning the support measures for whistleblowers. It is also not clearly defined which authority should establish that the whistleblower is "at risk" (the certification related to the fact that a person can benefit from protection is not regulated under national law). Furthermore, according to this Report, psychological support to whistleblowers should be provided by the government.

It should be noted that in 2015-2016, the government made plans for a new law in its draft anti-corruption programme, but finally, the issue completely disappeared..$^{42}$ However, a fully worked-out bill on an entirely new whistleblowing act ${ }^{43}$ was submitted to the Parliament in June 2015 (as an individual motion of a member of the Parliament ${ }^{44}$ ). The Committee on Legal Affairs of the Parliament refused to put this bill on the legislative agenda of the Parliament (on 28 ${ }^{\text {th }}$ September 2015). It was noted in the bill that even the government's anti-corruption strategy recognised shortcomings in the current rules of public interest whistleblower protection and the ineffectiveness of its current system, as it was also highlighted under the European Semester's latest report on the Hungarian economic environment. Therefore, the bill was aimed at reforming the law in an extremely progressive spirit, to a large extent by incorporating the above-cited proposals of NGOs. Accordingly, the bill contained some elementary reform proposals, among which the most notable ones were the following (without intending to be exhaustive here): the creation of a separate, dedicated so-called Public-Interest Protection Office (as part of the envisaged anti-corruption prosecutor's office); the reinforcement of the possibility of anonymous whistleblowing and whistleblowing via NGOs, trade unions, and journalists; the introduction of the reversal of the burden of proof; detailed rules on specific protections, remedies and support measures (including financial rewards) for whistleblowers; rules on public disclosures; protection for the relatives of the whistleblower; sanctions for reports made in bad faith etc.

40 K-Monitor, Hungarian Civil Liberties Union, 2015.

41 Report No. AJB-1873/2017 of the Commissioner, https://www.ajbh.hu/documents/10180/ $2602747 /$ Jelent $\%$ C3\%A9s+egy+k\%C3\%B6z\%C3\%A9rdek\%C5\%B1+bejelent $\% C 5 \% 91+$ vesz\%C3\%A9lyeztetetts\%C3\%A9g\%C3\%A9r\%C5\%91l+1873_2017/da2510cb-5353-cab8-b063eef3dd38e03b?version=1.0 accessed 01/09/2021.

42 The National Anti-Corruption Programme (2015-2018) did not contain such a goal any more.

43 T/5373, https://www.parlament.hu/irom40/05373/05373.pdf, accessed 01/09/2021.

44 T. Szabó, at that time independent MEP. 


\section{Reflections and tentative regulatory options in light of the Whistleblower Directive - from a labour law perspective}

As it was mentioned above, at the time of writing this paper, no official information is available on the Hungarian transposition (or related preparatory works) of the Whistleblower Directive. In any case, Member States are obliged to bring into force laws, regulations and administrative provisions necessary to comply with the Directive by 17 December 2021. Compared to the Pkbt., the regulation of the Directive is much more detailed and specific. Therefore, a medium-sized amendment to the law involving dozens of provisions is expected.$^{45}$ It is noteworthy that following the expiry of the previous anti-corruption programme in 2018, in June 2020, the government adopted a new Mid-term National Anti-corruption Strategy for 2020-2022 and an accompanying action plan. However, these documents contain no references to a reform of whistleblowing (even though whistleblowing is traditionally perceived as an element of anti-corruption in Hungary ${ }^{46}$ ).

Now, the most obvious, most challenging elements of the Directive upon which the Hungarian legislature will certainly need to act will be mentioned. On the most general level, it is obvious that the Directive's unique "three-tiered model of reporting" (including mandatorily set up internal, stable external and - as last resorts - public channels $)^{47}$ will not be easily adaptable to Hungary. In Hungary, as the paper has presented above, internal channels of whistleblowing ("hotlines") are not yet obligatory, the external channels are institutionally existent but rather weak, while public disclosures are not specifically regulated. The analysis below is inherently tentative and exploratory (taking into account that no official draft or proposal is available yet) and by no means exhaustive (rather illustrative) and deliberately puts the emphasis on the labour law-related aspects of the Directive and the regulation (as the Directive will influence labour law in a significant way in general $^{48}$ ). In light of all these disclaimers, the following regulatory issues seem to be the most striking in view of the Directive.

First, it is not clearly stated in Hungarian law that in the event of a legal dispute, in a case of alleged retaliation against whistleblowers, the employer has to prove that

45 Based on the general practice of Hungarian legal harmonisation, it is very unlikely that any draft or concept on the issue would be completed or any social consultation or social dialogue (if any) would take place much before the deadline. Furthermore, the situation is further complicated by the COVID-related legislation as a priority which basically occupies the Ministry of Justice in 2020-21.

46 Cf. J. Hajdú, A. Lukács, Whistleblowing és a közösségi média szerepe a korrupció elleni fellépésben (Whistleblowing and the role of social media in the fight against corruption), Nemzeti Közszolgálati Egyetem, Budapest 2018.

47 V. Abazi, The European Union Whistleblower Directive: A 'Game Changer' for Whistleblowing Protection?, Industrial Law Journal, Volume 49, Issue 4, December 2020, p. 650.

48 F. Kain, Whistleblowing and labour law: The Whistleblower Directive - development, content and obstacles, Italian Labour Law E-Journal 13(2), 2020, pp. 131-144. 
his or her action is not related to the public interest disclosure or that the disclosure was made in bad faith. The Directive (Recital 93) provides that once the reporting person demonstrates prima facie that he or she reported breaches or made a public disclosure in accordance with this Directive and suffered a detriment, the burden of proof should shift to the person who took the detrimental action, who should then be required to demonstrate that the action taken was not linked in any way to the reporting or the public disclosure. In other words, the reversed burden of proof is an important rule of the Directive [Article 21(5)], which needs to be introduced explicitly into Hungarian (labour) law.

Second, probably the most concrete obligation - obligation to establish internal reporting channels - in the Directive is laid down in Article 8(1), according to which "Member States shall ensure that legal entities in the private and public sector establish channels and procedures for internal reporting and for follow-up, following consultation and in agreement with the social partners ${ }^{49}$ where provided for by national law." As a main rule, the obligation applies to legal entities in the private sector with 50 or more workers. Reporting channels may be operated internally by a person or department designated for that purpose or provided externally by a third party. In sum, the Hungarian legislature will need to comply with this obligation and notify the Commission of any decision in this regard. Furthermore, the legislature, following an appropriate risk assessment taking into account the nature of the activities of the entities and the ensuing level of risk for, in particular, the environment and public health, may also require legal entities in the private sector with fewer than 50 workers to establish internal reporting channels and procedures.

Third, no specific protection is guaranteed for whistleblowers turning directly to the public (outside internal and external reporting channels) in Hungarian law (and more specifically in the Pkbt.). In light of the Directive (Article 15 on public disclosures), regulatory steps are certainly needed in this regard.

Fourth, the personal scope of the Directive (Article 4) is broader than that of the current Hungarian regulation. In brief, all persons who are in contact with the entity in the context of their "work-related activities" can report information on breaches. For instance, according to Article 4(2), the Directive applies also to reporting persons where they report or publicly disclose information on breaches acquired in a workbased relationship which has since ended (i.e. former employees). Furthermore, according to Article 4(3), the Directive applies to reporting persons whose work-based relationship is yet to begin in cases where information on breaches has been acquired

49 On the related potential roles of trade unions in general, see: EUROCADRES Best practice guide on whistleblowing for trade unions, https://whistleblowerprotection.eu/blog/best-practiceguide-on-whistleblowing-for-trade-unions/, accessed 01/09/2021. Furthermore, Abazi notes that "it is hoped that trade unions will play an active role in empowering whistleblowers' voices and advancing protection, not only through law but also through organizational culture." V. Abazi, The European Union Whistleblower Directive: A 'Game Changer' for Whistleblowing Protection?, Industrial Law Journal, Volume 49, Issue 4, December 2020, p. 656. In this regard, it is noteworthy that Hungarian trade unions are not active at all. 
during the recruitment process or other pre-contractual negotiations. As mentioned before, according to $\$ 14$ (1) Pkbt., internal whistleblower reports may be submitted by the employees of the employers or other persons having a contractual relationship with the employer organizations or persons having acceptable legitimate interest for submitting the whistleblower report or the remedying or discontinuation of the activity subject to the whistleblower report. Although the latter phrasing ("persons having acceptable legitimate interest") is broad enough, it is not especially precise.

Fifth, the Directive contains a very detailed regulation on protection measures (in Chapter VI), including prohibition of retaliation (Article 19), ${ }^{50}$ measures of support (Article 20), measures for protection against retaliation (Article 21), and measures for the protection of persons concerned (Article 22). Furthermore, effective, proportionate and dissuasive penalties or sanctions need to be institutionalised (Article 23), and Member States have to ensure that the rights and remedies provided for under the Directive cannot be waived or limited by any agreement, ${ }^{51}$ policy, form or condition of employment ("no waiver of rights and remedies," Article 24). The Hungarian regulatory framework surely needs more concretization on all of these points.

It ought to be noted that the material scope of the Directive (Article 2) does not cover labour law as such. The Directive lays down common minimum standards for the protection of persons reporting some pre-defined, listed breaches of Union law (falling within the scope of the Union acts set out in the Annex that concern the listed regulatory areas, including, for example, public procurement; financial services, products and markets, and prevention of money laundering and terrorist financing; product safety and compliance; transport safety; protection of the environment etc., but not European labour law and social policy). However, the Directive is without prejudice to the power of the Member States to extend protection under national law as regards areas or acts not covered by the Directive. Recital 5 of the Directive clearly encourages Member States to do so. In this regard, it is very unlikely that the Hungarian legislature would broaden the material scope, including for example labour law. The Directive itself still offers some room for optimism in this regard, as it stipulates in Article 27(3) that the Commission shall, by 17 December 2025, prepare a report assessing the impact of national law transposing this Directive. The report will evaluate the way in which the Directive has functioned and consider the need for additional measures, including, where appropriate, amendments with a view to extending the scope of the Directive to further Union acts or areas, in particular the improvement of the working environment to protect workers' health and safety and working conditions.

It is also noteworthy that in Hungary, there seems to be a preference in practice for anonymous reporting. ${ }^{52}$ However, the Directive basically leaves this issue up to

50 The list includes mostly (but not only) typical employer measures.

51 Including collective agreements.

52 E. Dénes, Whistleblowing: bejelentés vagy beárulás? (Whistleblowing: reporting or betrayal?), Munkajog (HVG-ORAC), 2020/4, p. 43. 
national law. Thus, according to the Directive, there is no compelling need to improve the existing regulation in this regard. Article 6(2) provides that without prejudice to the existing obligations to provide for anonymous reporting by virtue of Union law, the Directive does not affect the power of Member States to decide whether legal entities in the private or public sector and competent authorities are required to accept and follow up on anonymous reports of breaches.

\section{Conclusions}

The new Directive certainly contributes to a more uniform understanding of whistleblowing within the European Union. However, it is the task of the domestic legislators to give real "teeth" to the rather framework-like, technical standards of the Directive. It is difficult to predict, but it seems to be very unlikely that the Hungarian legislature would go much beyond the required minimum. On the other hand, it is very important to recall the fact that when dealing with whistleblowing, regulation is just one side of the coin and the de facto functionality of whistleblowing depends on many factors. As, for example, Abazi points out, "whether the Directive will attain the expected high standards of protection depends, inter alia, on the transposition of the rules into national law, the enforcement of the Directive's protections and the embeddedness of the rules in organizational culture." ${ }^{33}$ Ambrus also emphasises in a similar vein that "even the best-constructed whistleblowing system will remain ineffective if it is not used by employees." ${ }^{4}$ If one takes into account these observations, it is very difficult to be highly optimistic about the prospective success of the forthcoming Hungarian implementation of the Directive. No matter what legal framework on whistleblowing Hungary had, has or will have, the above-described country-specific cultural aversions, organisational and structural barriers and poor legal enforcement practices related to whistleblowing most certainly will not evaporate easily and quickly.

\section{Abstract}

The aim of this chapter is to take a general account of the past and current practices, experiences and challenges of whistleblowing legislation and whistleblower protection in Hungary. The emphasis will be put on the critical analysis of the currently effective regulatory environment of whistleblowing and whistleblower protection in Hungary, with specific regard to

53 V. Abazi, The European Union Whistleblower Directive: A 'Game Changer' for Whistleblowing Protection?, Industrial Law Journal, Volume 49, Issue 4, December 2020, p. 641.

54 I. Ambrus, Considerations for Assessing Corporate Wrongdoings - a Hungarian Approach to Whistleblowing, Elte Law Journal 2016/2, p. 22. 
labour law aspects. Furthermore, the context, prospects and basic requirements of the future implementation of the EU Directive will also be highlighted. In this vein, Section 2 sketches the historical, societal and constitutional context. Section 3, as the central part of this study, examines in detail the currently effective legislative framework of whistleblowing in Hungary. Section 4 deals specifically with the labour law-related aspects of whistleblowing, while Section 5 takes a brief look into other related fields of law (including anti-discrimination, criminal law, and trade secrets). Section 6 considers recent and relevant critical opinions and motions for reform. Section 7 looks into the possible challenges and the main tentative tasks of the upcoming transposition of the Directive into Hungarian law. Finally, Section 8 draws some broad, general conclusions.

\section{Bibliography}

Abazi V., The European Union Whistleblower Directive: A 'Game Changer' for Whistleblowing Protection?, Industrial Law Journal, Volume 49, Issue 4, December 2020.

Ambrus I., Considerations for Assessing Corporate Wrongdoings - a Hungarian Approach to Whistleblowing, Elte Law Journal 2016/2.

Dénes E., Whistleblowing: bejelentés vagy beárulás? (Whistleblowing: reporting or betrayal?), Munkajog (HVG-ORAC), 2020/4.

Gyulavári T., Kártyás G., The Hungarian Flexicurity Pathway? New Labour Code after Twenty Years in the Market Economy, Pázmány Press, Budapest 2015.

Hajdú J., Lukács A., Whistleblowing és a közösségi média szerepe a korrupció elleni fellépésben (Whistleblowing and the role of social media in the fight against corruption), Nemzeti Közszolgálati Egyetem, Budapest 2018.

Kain F., Whistleblowing and labour law: The Whistleblower Directive - development, content and obstacles, Italian Labour Law E-Journal, 2020.

K-Monitor, Hungarian Civil Liberties Union (2015): Submission to the Special Rapporteur on the promotion and protection of the right to freedom of opinion and expression on the Hungarian legal framework and practices governing whistleblower protection.

Kun A., A whistleblowerek védelme - különös tekintettel a munkajogi aspektusokra (Protection of whistleblowers - in particular labour law aspects), Pécsi Munkajogi Közlemények, 2011.

Kun A., International Research Project DIADSE (Dialogue for Advancing Social Europe), Country Report - Hungary, 2017; (Project financed by the EU, European Commission DG Employment, Social Affairs and Inclusion, Social Dialogue, Industrial Relations; Agreement number. VS/2014/0530), Project Management: Universiteit van Amsterdam, Hugo S. Instituut), http://hsi.uva.nl/en/diadse/reports/reports.html, accessed 01/09/2021. 